\title{
Estimation of Monthly Averaged Daily Solar Radiation with Sunshine Hours, Temperature, and Relative Humidity in Kathmandu, Nepal
}

\author{
B. P. Pant, B. Budha, K. N. Poudyal and B. Acharya
}

Journal of Nepal Physical Society

Volume 6, Issue 1, June 2020

ISSN: 2392-473X (Print), 2738-9537 (Online)

Editors:

Dr. Binod Adhikari

Dr. Manoj Kumar Yadav

Mr. Kiran Pudasainee

JNPS, 6 (1), 131-138 (2020)

DOI: http://doi.org/10.3126/jnphyssoc.v6i1.30562

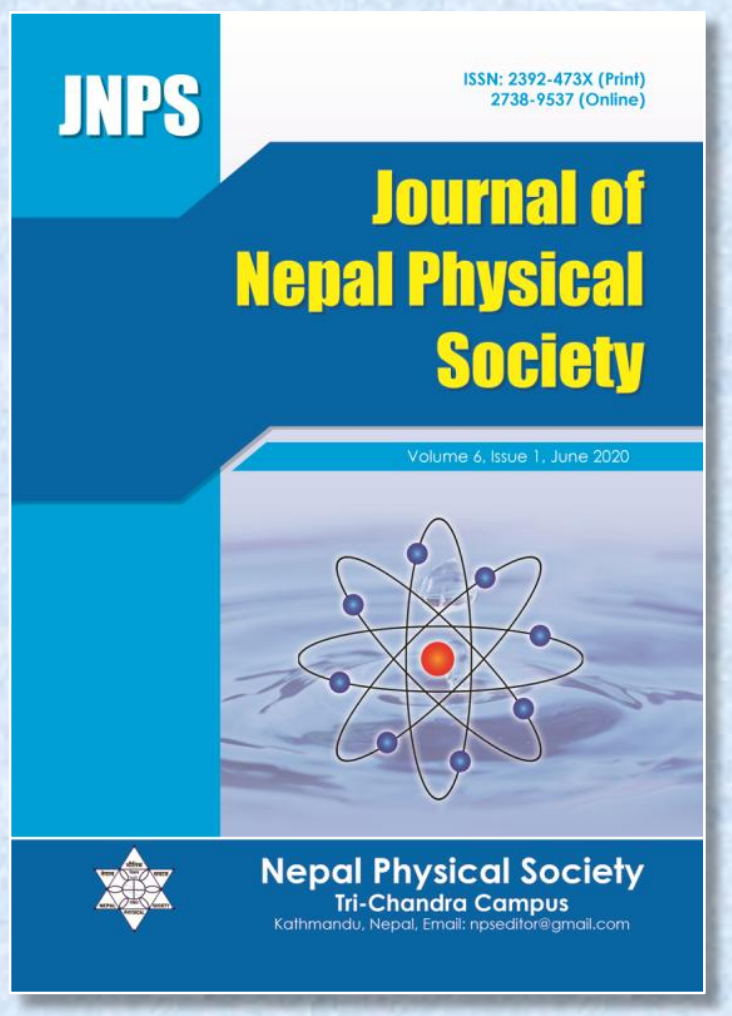

Published by:

Nepal Physical Society

P.O. Box: 2934

Tri-Chandra Campus

Kathmandu, Nepal

Email: npseditor@gmail.com 


\title{
Estimation of Monthly Averaged Daily Solar Radiation with Sunshine Hours, Temperature, and Relative Humidity in Kathmandu, Nepal
}

\author{
B. P. Pant ${ }^{1, *}$, B. Budha ${ }^{1}$, K. N. Poudyal ${ }^{2}$ and B. Acharya ${ }^{1}$ \\ ${ }^{1}$ St.Xavier's College, Maitighar, Kahmandu, Nepal \\ ${ }^{2}$ Institute of Engineering Pulchowk Campus, Lalitpur, Nepal \\ *Corresponding author: birendra@sxc.edu.np/ ptbiren@gmail.com
}

Received: 12 Apr., 2020; Revised: 12 May, 2020; Accepted: 28 Jun., 2020

\begin{abstract}
This study is mainly concerned with the performance of various single and multiple meteorological parameter models to estimate the global solar radiation (GSR) on the horizontal site of Kathmandu, Nepal located at $27.69^{\circ} \mathrm{N}, 85.35^{\circ} \mathrm{E}$ at an altitude of 1338 meter from the sea level. The main concern of this research is to evaluate the preciseness and appropriateness of various models and to do that we have implemented diverse statistical tests. The results exhibit that all the used models have a good correlation for the determination of monthly averaged daily global solar radiation on the horizontal site of Kathmandu. Nonetheless, the sunshine hour and temperature-based model have shown a better agreement between the measured and estimated GSR of the studied site with RMSE and $\mathrm{R}^{2}$ values 0.88 and 0.87 , respectively. The value of correlation coefficients a, b and c are found to be $0.42,0.53$, and 0.01 , successively.
\end{abstract}

Keywords: Empirical models, Global solar radiation, Regression constants, Statistical error, Sunshine hour.

\section{BACKGROUND}

For the sustainable development of a country energy has become a crucial factor. The continual use of the non-renewable source of energy like fossil fuels has led them towards the verge of destruction and such energies are not environment-friendly either [1]. So, looking at this context renewable sources of energy will help to suffice the increasing energy crisis and somehow will control the depletion of fossil fuels. Solar radiation is one of the perpetual sources of energy and the earth's primary source of energy provides $99.97 \%$ of the heat energy required for various chemo-physical processes [2]. Almost every form of energy in the earth is the ultimate product of solar radiation and also solar energy is abundant, accessible, and pollution-free, which makes it ecofriendly and the cheapest among the other sources of energy [3, 4]. When nuclear fusion reaction takes place in the sun, solar radiation is emitted in the form of electromagnetic radiation, some solar radiation is reflected, some are absorbed, and some are diffused. Thus, only a few parts of the solar radiation reach the earth's surface. Solar radiation diffused by earth's atmosphere have not a unique direction and the sum direct/beam and diffused solar radiation received by a particular site is called Global Solar Radiation [5, 6]. Global Solar Radiation plays an important role in the development design and performance of solar technologies and its implementation like a photovoltaic and solar thermal system of a particular place [7]. Apart from these, it can also be used in various fields such as in power plants, agriculture, architectural design, and various meteorological modeling. Also, the technology set up for the utilization of solar energy is eco-friendly. This includes solar panels, solar heaters, and so on [8].

There are a lot of places in Nepal where the data on solar radiation are still unavailable even though Nepal receives quite a good amount of solar radiation. Based on various studies in the context of Nepal it has been revealed that average sunshine days annually are 300 and average solar energy per year is $4.7 \mathrm{KWh} / \mathrm{m}^{2} /$ day [9]. This can be considered a suitable volume. By the use of a solar pyranometer, we can measure the Global Solar Radiation of a particular place effectively. But this method seems to be very expensive. Due to this fact, we have to approach a different method which 
should quite economical and more fruitful. So, to find the GSR of a place we set out some models and use the meteorological parameters like humidity, temperature, sunshine hours, etc. There are various types of empirical formulae for determining the monthly mean daily GSR as a function of various determined climate factors. It is believed that Angstrom-Prescott is the simplest regression relation and it determines GSR as a function of hours of bright sunshine [10].

In the context of Nepal, the energy crisis has been roaring and considering these facts, access to solar data and technologies is extremely important. So our study aims to provide access to various solar energy data by using different models based on the different meteorological parameters and helps various agencies and organizations develop solar technologies.

\section{Nomenclature}

\begin{tabular}{|c|c|}
\hline $\mathrm{Hg}$ & $\begin{array}{l}\text { Monthly average daily global solar } \\
\text { radiation on the horizontal surface of } \\
\text { selected location }\left(\mathrm{MJm}^{-2} \mathrm{day}^{-1}\right)\end{array}$ \\
\hline Ho & $\begin{array}{l}\text { Monthly average daily extraterrestrial } \\
\text { solar radiation }\left(\mathrm{MJm}^{-2} \mathrm{day}^{-1}\right)\end{array}$ \\
\hline Tmax & $\begin{array}{l}\text { Monthly average daily maximum } \\
\text { temperature }\left({ }^{\circ} \mathrm{C}\right)\end{array}$ \\
\hline Tmin & $\begin{array}{l}\text { Monthly average daily minimum } \\
\text { temperature }\left({ }^{\circ} \mathrm{C}\right)\end{array}$ \\
\hline S & $\begin{array}{l}\text { Monthly average daily hours of bright } \\
\text { sunshine (h) }\end{array}$ \\
\hline So & Monthly average day length (h) \\
\hline Isc & Solar constant $\left(=1367 \mathrm{Wm}^{-2}\right)$ \\
\hline $\mathrm{N}$ & $\begin{array}{l}\text { Number of days starting from first } \\
\text { January }\end{array}$ \\
\hline RMSE & Root- mean square error $\left(\mathrm{MJm}^{-2} \mathrm{day}^{-1}\right)$ \\
\hline MBE & Mean bias error \\
\hline MPE & Mean percentage error $(\%)$ \\
\hline MABE & Mean absolute bias error $\left(\mathrm{MJm}^{-2} \mathrm{day}^{-1}\right)$ \\
\hline
\end{tabular}

$\begin{array}{|ll|}\text { MAPE } & \text { Mean absolute percentage error }(\%) \\ \text { GSR } & \text { Global solar radiation }\left(\mathrm{MJm}^{-2} \text { day }^{-1}\right) \\ \text { a-d } & \text { Regression coefficients } \\ \text { Greek letters } \\ \begin{array}{ll}\text { Ws } & \text { Mean sunshine hour angle for the given } \\ & \text { month }\left(^{\circ}\right) \\ \phi & \text { Latitude of the site }\left(^{\circ}\right) \\ \delta & \text { Solar declination angle }\left(^{\circ}\right)\end{array}\end{array}$

\section{DESCRIPTION OF THE SITE AND APPROACH OF DATA ANALYSIS}

Nepal receives a good amount of solar radiation due to its geographical location, so does Kathmandu. Kathmandu is geographically a beautiful place located in the central region of Nepal. The monthly averaged daily solar radiations, sunshine duration, and daily temperature data have been collected from the Department of Hydrology and Meteorology (DHM) Government of Nepal for the year 2015. Due to the unavailability of data, we constraints our study for one year.

To measure the radiation data on the ground surface, CMP6 pyranometer is used. The functioning temperature of CMP6 pyranometer is in the range of $-40 \mathrm{o} \mathrm{C}$ to $80 \mathrm{o} \mathrm{C}$ and the spectral range of the device is $310 \mathrm{~nm}$ to $2800 \mathrm{~nm}$. The field and sensitivity of the user device are $180 \mathrm{o}$ and 5215 $\mu / \mathrm{V} / \mathrm{W} / \mathrm{m} 2$ respectively. The resolution of the device is one minute for 24 hours and the LOG BOX SD data logger is used to record the data. The device is suitable for all weather condition and can collect real time data. Further, it has special features like lower power consumption, optimum resolution, and low noise. In the device $128 \mathrm{~KB}$ memory is available and for further memory requirement, we can insert an SD memory card for a long time data recording procedure. The communication port used by LOG BOX is either RS232 or RS 485 [11].

Table 1: Geographical location of the studied site [1]

\begin{tabular}{llllll}
\hline Region & Site & Latitude $\left({ }^{\mathbf{0}} \mathbf{N}\right)$ & Longitude $\left({ }^{\mathbf{0}} \mathbf{E}\right)$ & Elevation $(\mathbf{m})$ & Year \\
\hline Central & Kathmandu & 27.69 & 85.35 & 1338 & 2015 \\
\hline
\end{tabular}

\section{SELECTED MODELS FOR THE DETERMINATION OF GSR}

In order to determine GSR for the studied site a total of thirteen different meteorological parameters based model were selected. Depending on the input parameters the models are classified into four categories. 


\subsection{Sunshine hour based models}

\subsubsection{Angstrom-Prescott model [12]}

Angstrom and Prescott formulated the relation for the determination of GSR. It is the most suitable and widely accepted model based on the sunshine hour. The mathematical relationship for this model is shown below:

$$
\frac{\mathrm{Hg}}{\mathrm{Ho}}=\mathrm{a}+\mathrm{b}\left(\frac{\mathrm{S}}{\mathrm{So}}\right)
$$

$$
\text { Ho }=\frac{24}{\pi} \operatorname{Isc}\left\{1+0.033 \cos \left(\frac{360 \mathrm{n}}{365}\right)\right\} *\left\{\cos (\phi) \cos (\delta) \sin (\mathrm{Ws})+\frac{2 \pi \mathrm{Ws}}{360} \sin (\phi) \sin (\delta)\right\}
$$

Isc is the solar constant and is defined as the flux density which measures solar radiation per unit area. Its value is $1367 \mathrm{Wm}^{-2}$.

$\phi$ is latitude of the location,

$\delta$ is solar declination angle

Ws is mean sunshine hour angle for a given month and $\mathrm{n}$ is number of year starting from January first

For a month $\phi$ and $\delta$ can be calculated using the equation [13]

$$
\delta=23.45 \sin \left\{\frac{360(\mathrm{n}+284)}{365}\right\}
$$

$\delta$ is in degree

Ws $=\cos ^{-1}[-\tan \delta \tan \phi]$

The sunshine duration for a month (So) can be calculated using the equation,

So $=\frac{2}{15} \mathrm{Ws}$

\subsubsection{Ogelman et.al model [14]}

The second order form of Angstrom-Prescott model is Ogelman et.al model and used sunshine hour as input parameter.

$$
\frac{\mathrm{Hg}}{\mathrm{Ho}}=\mathrm{a}+\mathrm{b}\left(\frac{\mathrm{S}}{\mathrm{So}}\right)+\mathrm{c}\left(\frac{\mathrm{S}}{\mathrm{So}}\right)^{2}
$$

Where a, b, c are empirical coefficients

\subsubsection{Samuel model [15]}

Third order modified form of Angstrom-Prescott model is Samuel model.

$$
\frac{\mathrm{Hg}}{\mathrm{Ho}}=\mathrm{a}+\mathrm{b}\left(\frac{\mathrm{S}}{\mathrm{So}}\right)+\mathrm{c}\left(\frac{\mathrm{S}}{\mathrm{So}}\right)^{2}+\mathrm{d}\left(\frac{\mathrm{S}}{\mathrm{So}}\right)^{3}
$$

Where a, b, c, d are empirical coefficients

\subsubsection{Bakirci model [16]}

The linear, exponential and power form of model is Bakirci model.
Where $\mathrm{Hg}$ is the calculated monthly average daily global solar radiation on a horizontal surface $\mathrm{MJ} / \mathrm{m}^{2} /$ day. Ho is the Monthly average daily extraterrestrial radiation $\left(\mathrm{MJ} / \mathrm{m}^{2}\right.$ day), $\mathrm{S}$ is the monthly average daily hours of bright sunshine, so empirical coefficients.

Ho can be determined using the equation [13] $=$ the monthly average day length and $\mathrm{a}, \mathrm{b}$ are

Where a, b, c are empirical constants.

\subsubsection{Newland model [17]}

The linear logarithmic model is Newland model.

$$
\frac{\mathrm{Hg}}{\mathrm{Ho}}=\mathrm{a}+\mathrm{b}\left(\frac{\mathrm{S}}{\mathrm{So}}\right)+\operatorname{cog}\left(\frac{\mathrm{S}}{\mathrm{So}}\right)
$$

Where a, b, c are empirical constants.

\subsection{Temperature based models}

\subsubsection{Angstrom type regression model [18]}

Regression type temperature dependent modified form of Angstrom type model.

$$
\frac{\mathrm{Hg}}{\mathrm{Ho}}=\mathrm{a}+\mathrm{b}\left(\frac{\mathrm{Tmax}}{\mathrm{Tmin}}\right)
$$

Where Tmax and Tmin are average monthly maximum and minimum temperature, $\mathrm{a}$ and $\mathrm{b}$ are empirical constants.

\subsubsection{Chen et.al model [19]}

$$
\frac{\mathrm{Hg}}{\mathrm{Ho}}=\mathrm{a}(\operatorname{Tmax}-\mathrm{Tmin})^{\frac{1}{2}}+\mathrm{b}
$$

where $\mathrm{a}$ and $\mathrm{b}$ are empirical coeficients.

\subsection{Relative humidity based models}

3.3.1 Angstrom -Prescott type relative humidity based model [20]

$\frac{\mathrm{Hg}}{\mathrm{Ho}}=\mathrm{a}+\frac{\mathrm{b}(\mathrm{RH})}{100}$

Where RH is the average monthly relative humidity and $\mathrm{a}, \mathrm{b}$ are empirical constants. 
3.3.2 Hargreaves and Samani temperature type model [21]

$\frac{\mathrm{Hg}}{\mathrm{Ho}}=\mathrm{a}+\mathrm{b}(\mathrm{RH})^{2}$

In the above equation $\mathrm{a}, \mathrm{b}$ are empirical constants and $\mathrm{RH}$ is relative humidity.

\subsection{Multiple parameters based models}

The models under this category use multiple meteorological parameters as input parameters

3.4.1 In this type of model, clearness index $(\mathrm{Hg} / \mathrm{Ho})$ is correlated with multiple meteorological parameters [22].
$\frac{\mathrm{Hg}}{\mathrm{Ho}}=\mathrm{a}+\mathrm{b}\left(\frac{\mathrm{s}}{\mathrm{So}}\right)+\mathrm{c}(\mathrm{Tmax})$

3.4.2 In this model the sunshine hour and relative humidity are correlated with the clearness index [22].

$$
\begin{aligned}
& \frac{\mathrm{Hg}}{\mathrm{Ho}}=\mathrm{a}+\mathrm{b}\left(\frac{\mathrm{S}}{\mathrm{So}}\right)+\frac{\mathrm{c}(\mathrm{RH})}{100} \ldots \\
& \frac{\mathrm{Hg}}{\mathrm{Ho}}=\mathrm{a}+\mathrm{b}\left(\frac{\mathrm{S}}{\mathrm{So}}\right)+\mathrm{c}(\mathrm{RH}) .
\end{aligned}
$$

3.4.3 This type of model correlates sunshine hour, temperature and relative humidity with clearness index [22].

$$
\frac{\mathrm{Hg}}{\mathrm{Ho}}=\mathrm{a}+\mathrm{b}\left(\frac{\mathrm{S}}{\mathrm{So}}\right)+\mathrm{c}(\mathrm{Tmax})+\frac{\mathrm{d}(\mathrm{RH})}{100}
$$

\begin{tabular}{|c|c|c|c|}
\hline Model & Symbol & $\begin{array}{l}\text { Parameter } \\
\text { required }\end{array}$ & Relation \\
\hline Angstrom -Prescott model [12] & M 1 & S, So & $\frac{\mathrm{Hg}}{\mathrm{Ho}}=\mathrm{a}+\mathrm{b}\left(\frac{\mathrm{S}}{\mathrm{So}}\right)$ \\
\hline Ogelman et.al model [13] & M2 & S, So & $\frac{\mathrm{Hg}}{\mathrm{Ho}}=\mathrm{a}+\mathrm{b}\left(\frac{\mathrm{s}}{\mathrm{So}}\right)+\mathrm{c}\left(\frac{\mathrm{s}}{\mathrm{So}}\right)^{2}$ \\
\hline $\begin{array}{l}\text { Third order Angstrom-Prescott type } \\
\text { model [14] }\end{array}$ & M3 & S, So & $\frac{\mathrm{Hg}}{\mathrm{Ho}}=\mathrm{a}+\mathrm{b}\left(\frac{\mathrm{s}}{\mathrm{So}}\right)+\mathrm{c}\left(\frac{\mathrm{s}}{\mathrm{So}}\right)^{2}+\mathrm{d}\left(\frac{\mathrm{s}}{\mathrm{So}}\right)^{3}$ \\
\hline Bakirci model [15] & M4 & S , So & $\frac{\mathrm{Hg}}{\mathrm{Ho}}=\mathrm{a}+\mathrm{b}\left(\frac{\mathrm{S}}{\mathrm{So}}\right)+\operatorname{cexp}\left(\frac{\mathrm{S}}{\mathrm{So}}\right)$ \\
\hline Newland model [16] & M5 & S, So & $\frac{\mathrm{Hg}}{\mathrm{Ho}}=\mathrm{a}+\mathrm{b}\left(\frac{\mathrm{S}}{\mathrm{So}}\right)+\operatorname{clog}\left(\frac{\mathrm{S}}{\mathrm{So}}\right)$ \\
\hline Angstrom type regression model [17] & M6 & Tmax , Tmin & $\frac{\mathrm{Hg}}{\mathrm{Ho}}=\mathrm{a}+\mathrm{b}\left(\frac{\mathrm{Tmax}}{\mathrm{Tmin}}\right)$ \\
\hline Chen et.al model [18] & M7 & Tmax , Tmin & $\frac{\mathrm{Hg}}{\mathrm{Ho}}=\mathrm{a}(\operatorname{Tmax}-\operatorname{Tmin})^{\frac{1}{2}}+\mathrm{b}$ \\
\hline $\begin{array}{l}\text { Angstrom -Prescott type relative } \\
\text { humidity based model [19] }\end{array}$ & M8 & $\mathrm{RH}$ & $\frac{\mathrm{Hg}}{\mathrm{Ho}}=\mathrm{a}+\frac{\mathrm{b}(\mathrm{RH})}{100}$ \\
\hline $\begin{array}{l}\text { Hargreaves and Samani temperature } \\
\text { type model [20] }\end{array}$ & M9 & $\mathrm{RH}$ & $\frac{\mathrm{Hg}}{\mathrm{Ho}}=\mathrm{a}+\mathrm{b}(\mathrm{RH})^{2}$ \\
\hline $\begin{array}{l}\text { Multiple parameter based models } \\
\text { [21] }\end{array}$ & M10 & $\mathrm{S}, \mathrm{So}$,Tmax & $\frac{\mathrm{Hg}}{\mathrm{Ho}}=\mathrm{a}+\mathrm{b}\left(\frac{\mathrm{s}}{\mathrm{So}}\right)+\mathrm{c}(\operatorname{Tmax})$ \\
\hline $\begin{array}{l}\text { Multiple parameter based models } \\
\text { [21] }\end{array}$ & M11 & $\mathrm{S}, \mathrm{So}, \mathrm{RH}$ & $\frac{\mathrm{Hg}}{\mathrm{Ho}}=\mathrm{a}+\mathrm{b}\left(\frac{\mathrm{S}}{\mathrm{So}}\right)+\frac{\mathrm{c}(\mathrm{RH})}{100}$ \\
\hline $\begin{array}{l}\text { Multiple parameter based models } \\
\text { [22] }\end{array}$ & M12 & $\mathrm{S}, \mathrm{So}, \mathrm{RH}$ & $\frac{\mathrm{Hg}}{\mathrm{Ho}}=\mathrm{a}+\mathrm{b}\left(\frac{\mathrm{S}}{\mathrm{So}}\right)+\mathrm{c}(\mathrm{RH})$ \\
\hline
\end{tabular}

Table 1 : List of models used for the determination of global solar radiation

\section{METHODOLOGY, COMPARISON TECHNIQUES OF USED MODELS AND THEIR VALIDATION}

The value of GSR on the horizontal site was measured using the CMP6 pyranometer. The monthly averaged daily value of extraterrestrial solar radiation and day length were evaluated using the equations described in the above section. The values of the regression constants used in each model were calculated using the regression analysis process. The performance of the various model is evaluated based on statistical tests like; MPE (Mean 
percentage error), RMSE (Root Mean Square Error), MBE (Mean Bias Error), MAPE (Mean Absolute Percentage Error), MABE (Mean Absolute Bias Error) and other factors including correlation coefficient (r) and coefficient of determination $\left(\mathrm{R}^{2}\right)$.These Statistical tests are defined as below $[1,18,23,24]$;

$$
\begin{aligned}
& \text { MPE }=\frac{1}{\mathrm{~N}} \sum_{\mathrm{i}=1}^{\mathrm{N}}\left(\frac{\mathrm{H}_{\mathrm{c}}-\mathrm{H}_{\mathrm{m}}}{\mathrm{H}_{\mathrm{m}}}\right) \mathrm{X} 100 \\
& \text { MAPE }=\frac{1}{\mathrm{~N}} \sum_{\mathrm{i}=1}^{\mathrm{N}}\left|\frac{\mathrm{H}_{\mathrm{c}}-\mathrm{H}_{\mathrm{m}}}{\mathrm{H}_{\mathrm{m}}}\right| \mathrm{X} 100 \% \\
& \mathrm{MABE}=\frac{1}{\mathrm{~N}} \sum_{\mathrm{i}=1}^{\mathrm{N}}\left|\mathrm{H}_{\mathrm{c}}-\mathrm{H}_{\mathrm{m}}\right| \mathrm{MJ} / \mathrm{m}^{2} / \text { day. } \\
& \mathrm{MBE}=\frac{1}{\mathrm{~N}} \sum_{\mathrm{i}=1}^{\mathrm{N}}\left(\mathrm{H}_{\mathrm{c}}-\mathrm{H}_{\mathrm{m}}\right) \mathrm{MJ} / \mathrm{m}^{2} / \text { day } . \\
& \text { RMSE }=\left[\frac{1}{\mathrm{~N}} \sum_{\mathrm{i}=1}^{\mathrm{N}}\left(\mathrm{H}_{\mathrm{c}}-\mathrm{H}_{\mathrm{m}}\right)^{2}\right]^{\frac{1}{2}} \quad \mathrm{MJ} / \mathrm{m}^{2} / \text { day } \ldots . . \\
& \mathrm{R}^{2}=\frac{\left[\sum_{\mathrm{i}=1}^{\mathrm{N}}\left(\mathrm{H}_{\mathrm{c}}-\mathrm{H}_{\mathrm{c}, \text { avg }}\right)\left(\mathrm{H}_{\mathrm{m}}-\mathrm{H}_{\mathrm{m}, \mathrm{avg}}\right)\right]^{2}}{\sum_{\mathrm{i}-1}^{\mathrm{N}}\left(\mathrm{H}_{\mathrm{c}}-\mathrm{H}_{\mathrm{c}, \text { avg }}\right)^{2}\left(\sum_{\mathrm{i}=1}^{\mathrm{N}} \mathrm{H}_{\mathrm{m}}-\mathrm{H}_{\mathrm{m}, \mathrm{avg}}\right)^{2}} \ldots \ldots \ldots \ldots \\
& r=\frac{\sum_{i=1}^{N}\left(H_{m}-\overline{H_{m}}\right)\left(H_{c}-\overline{H_{c}}\right)}{\left[\sum_{i=1}^{N}\left(H_{m}-\overline{H_{m}}\right)^{2}\left(\sum_{i=1}^{N}\left(H_{c}-\overline{H_{c}}\right)^{2}\right)\right]^{\frac{1}{2}}}
\end{aligned}
$$

Table 3: Statistical indicators for empirical models employed in Kathmandu Nepal

\begin{tabular}{lrrlllll}
\hline Model & $\mathbf{r}$ & $\mathbf{R}^{\mathbf{2}}$ & $\begin{array}{c}\text { MPE } \\
(\boldsymbol{\%})\end{array}$ & $\begin{array}{c}\text { MAPE } \\
(\boldsymbol{\%})\end{array}$ & $\begin{array}{c}\text { MABE } \\
\left(\mathbf{M J} / \mathbf{m}^{2} / \mathbf{d a y}\right)\end{array}$ & $\begin{array}{c}\text { MBE } \\
\left(\mathbf{M J} / \mathbf{m}^{2} / \mathbf{d a y}\right)\end{array}$ & $\begin{array}{c}\mathbf{R M S E} \\
\left(\mathbf{M J} / \mathbf{m}^{\mathbf{2}} / \mathbf{d a y}\right)\end{array}$ \\
\hline M1 & 0.85 & 0.71 & 0.42 & $8.15 \%$ & 1.02 & 0.09 & 1.41 \\
M2 & 0.84 & 0.70 & 1.05 & $7.82 \%$ & 0.98 & 0.16 & 1.40 \\
M3 & 0.84 & 0.71 & 0.44 & $8.14 \%$ & 1.02 & 0.08 & 1.40 \\
M4 & 0.84 & 0.71 & 1.02 & $7.86 \%$ & 0.99 & 0.08 & 1.41 \\
M5 & 0.84 & 0.71 & 1.21 & $7.97 \%$ & 1.00 & 0.18 & 1.43 \\
M6 & 0.30 & 0.09 & 2.58 & $13.66 \%$ & 1.65 & 0.09 & 2.07 \\
M7 & 0.84 & 0.70 & 0.59 & $10.26 \%$ & 1.27 & 0.10 & 1.43 \\
M8 & 0.24 & 0.06 & 6.24 & $22.21 \%$ & 2.54 & 0.56 & 3.13 \\
M9 & 0.26 & 0.06 & 6.17 & $22.21 \%$ & 2.55 & 0.56 & 3.12 \\
M10 & 0.94 & 0.87 & 3.00 & $5.24 \%$ & 0.63 & 0.33 & 0.88
\end{tabular}

Where $\mathrm{H}_{\mathrm{m}}$ is the measured value, $\mathrm{H}_{\mathrm{c}}$ is the calculated value of solar radiation and $\mathrm{n}$ is the number of comparisons, $\mathrm{H}_{\mathrm{m}, \mathrm{avg}}$ is average of measured value of solar radiation, $\mathrm{H}_{\mathrm{c}, \mathrm{avg}}$ is the average of calculated value of solar radiation, $\overline{\mathrm{H}}$ is mean value of radiation, $\overline{\mathrm{H}_{\mathrm{m}}}$ is mean measured solar radiation and $\overline{\mathrm{H}_{\mathrm{c}}}$ is mean calculated solar radiation. The units of radiation are $\mathrm{MJ} / \mathrm{m}^{2} /$ day.

\subsection{Significance of Statistical Parameters:}

The model has better performance when the value of RMSE is smaller. RMSE is always positive. If the value is closest to zero, then the model is considered ideal. The coefficient of determination $\mathrm{R}^{2}$ specified how correctly model estimates trend in the calculated data; the model is more illustrative when $\mathrm{R}^{2}$ approaches close to 1 . Finally, the correlation coefficient ' $r$ 'evaluates the strength and direction of the linear interrelationship between two variables on a scatter plot diagram. The r-value always lies in the range of +1 to $-1[1,25]$. The value of MBE and MPE should be low for the model to be more practical. They provide information about the long term performance of a model. The negative and positive value of MPE gives underestimation and overestimation of calculated value and low value of MPE is favorable in the result. When MBE is so close to zero, the model is more accurate [26]. Finally, for higher accuracy of the model RMSE, MBE, MABE, and MPE error indicator should be close to zero. Table 3 below shows the result of the various statistical tests for the models used. 


\begin{tabular}{llllllll} 
M11 & 0.82 & 0.67 & 0.74 & $7.61 \%$ & 0.95 & 0.05 & 1.17 \\
M12 & 0.80 & 0.64 & 7.38 & $10.28 \%$ & 1.23 & 0.86 & 1.49 \\
M13 & 0.90 & 0.82 & -2.45 & $6.04 \%$ & 0.79 & -0.36 & 0.80 \\
\hline
\end{tabular}

\section{RESULTS AND DISCUSSION}

This study uses 13 different meteorological parameters based models for the determination of global solar radiation. The calculated values of GSR using the models described above were compared to the measured value of GSR. To find how good the models are we performed various statistical tests like RMSE, MBE, MPE, MABE, MAPE, $r$ and $R^{2}$. The results of these tests were described in table 3. Also, empirical coefficients obtained by data analysis regression technique for all implemented models are condensed in table 4.

Table 4: Empirical coefficients for the used models

\begin{tabular}{lllll}
\hline Model & a & B & C & d \\
\hline M1 & 0.61 & 0.71 & & \\
M2 & 0.11 & 0.47 & 0.28 & -8.06 \\
M3 & 0.71 & -4.08 & 11.02 & \\
M4 & -0.24 & 0.19 & 0.34 & \\
M5 & 0 & 0.79 & & \\
M6 & 0.25 & 0.06 & & \\
M7 & 0.26 & -0.53 & & \\
M8 & 0.45 & -0.50 & & \\
M9 & 0.44 & 0.05 & 0.01 & \\
M10 & 0.42 & 0.53 & 0.37 & \\
M11 & -0.26 & 0.80 & 0.04 & \\
M12 & -0.26 & 0.80 & -0.01 & \\
M13 & 0.34 & 0.56 & & \\
\hline
\end{tabular}

On the basis of the statistical test model involving sunshine hour and temperature as input parameter shows a better agreement with the measured value of radiation. The value of empirical coefficients obtained from the data analysis regression tool for implemented models is presented in table 4. The value of $\mathrm{a}, \mathrm{b}$, and $\mathrm{c}$ for model 10 (selected model) are found to be $0.42,0.53$, and 0.01 , respectively. The figure below shows the comparative study of measured and calculated values of global solar radiation and it has been revealed that observed value and estimated value are in good agreement for the model based on sunshine hour and temperature. In our previous study of estimation of global solar radiation in different sites of Nepal, model based on temperature and sunshine hour as input parameter perform well among the used models [1]. Therefore, it can be concluded that empirical models based on temperature and sunshine hour show a higher degree of correlation with the measured value. Form the figure below it has been revealed that there is a strong correlation between measured and calculated value for the selected model.

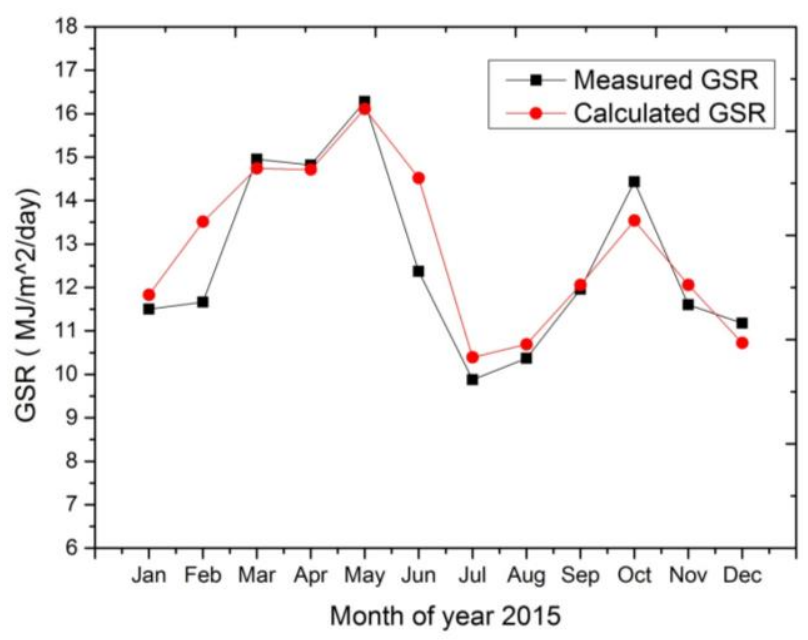

Fig. 1: Comparative study of measured and calculated global solar radiation for Kathmandu using model 10 
The radiation received by a particular location depends upon the duration of radiation and intensity. From the above graph, it can be inferred that radiation received in the month of April and May is more compared to another month of the year. The reason for the maximum radiation is mainly due to less cloud coverage, less rainfall, and less value of solar zenith angle. On the other hand, the radiation value has declined in the month of June, July, and August for the studied site due to the fact that they are rainy season and maximum rainfall of the year occurs in these months [1]. During rainy season sky over the studied site is covered with cloud and this reduces radiation reaching to the ground surface. Meteorological parameters like temperature, daily sunshine hour, rainfall, humidity, and cloud coverage not only affect the radiation received by the ground surface. Other factors such as solar declination angle, hour angle variation, solar zenith angle and physical factors such as scattering of air molecules, water vapor content and local level pollution also play a key role for the radiation received by the ground surface. So it is essential to consider these factors for the accurate measurement of radiation for the particular geographical location for better solar energy utilization.

\section{CONCLUSIONS}

In this study for the estimation of global solar radiation, we have employed thirteen singlemultiple meteorological parameters models. The preciseness of different models is evaluated based on multiple statistical tests such as; MPE, MAPE, MABE, MBE, RMSE, $R^{2}$, and $r$. Based on statistical interpretation, the obtained result uncover that the model based on temperature, sunshine hour as input parameter shows a good correlation between the observed and estimated value of global solar radiation. However, sunshine hour and temperature-based model (M10) performs best among the used models with $\mathrm{RMSE}=0.88$, MBE $=0.33, \quad$ MABE $=0.63, \quad$ MPE $=3.0$, MAPE $=5.24 \%$, and $R^{2}=0.87$. The smaller RMSE, MABE, and MPE value of the above model show the used model performs better and shows higher accuracy than other models. The positive value of MPE gives an overestimation of obtained value and lover value of MPE is favorable for the result. The correlation coefficients $\mathrm{a}, \mathrm{b}$ and $\mathrm{c}$ are found to be $0.42,0.53$, and 0.01 , respectively and this value shows model perform well among the other model. The global solar radiation measured from the meteorological parameters provides an alternative in the absence of measured solar radiation. Empirical models based on temperature and sunshine hour as an input parameter can be considered as an advantageous tool for the determination of solar radiation. The highly correlated equations mentioned in this study will allow the solar researcher to use them as they are in close agreement with measured value and may be applicable in a similar geographical location throughout the world.

\section{ACKNOWLEDGEMENT}

Authors are grateful to the Department of Hydrology and Meteorology (DHM), Government of Nepal for the various meteorological data used in this research work.

\section{REFERENCES}

[1] Pant, B. P., Poudyal, K. N., Acharya, B., and Budha, B. Empirical models for the evaluation of global solar radiation in the different sites of Nepal. JNPS, 5 (1), 67-73 (2019).

[2] Emmanuel, Q., Leonard, K.A., Kwasi, P., Jeffrey, A., Osei, R. B., Dziewornu, B. and Mubarick, R. S. Empirical models for estimating Global Solar Radiation over the Ashanti region of Ghana. Journal of Solar Energy, 2014, 1-6 (2014).

[3] Shakya, S., Pant, B. P. and Jha, V. K. Determination of the optimal tilt angle for a tilted solar panel in Kathmandu, Nepal using isotropic model. Research Journal of Physical Sciences, 7(2), 8-14 (2019).

[4] Okonkwo, G. N. and Nwokoye , A. O. C. Estimation of Global Solar Radiation from temperature Data in Minna location. Journal of Applied Physics, 6(3), 1-6 (2014).

[5] Gana, N. N., Rai, J. K. and Momoh, M. Estimation of Global and Diffuse Solar Radiation for Kebbi, North Western Nigeria. Advances in Applied Science Research, 4(5), 409-421 (2013).

[6] Okoli, N. L. Estimation of Global Solar Radiation using sunshine and Temperature based models for Oko Town in Anatara, Nigeria. American Journal of Renewable and Sustainable Energy, 3 (2), 8-14 (2017).

[7] Poudyal, K. N. Estimation of Global Solar Radiation using modified Angstrom Empirical formula on the basis of Meteorological parameter in Himalaya region, Pokhara, Nepal. Journal of Institute of Engineering, 11 (1), 158-164 (2015).

[8] Medugu, D.W., Adisa, A. B., Burari, F. W. and Abdul'Azeez, M. A. Solar Radiation: Correlation between measured and predicted values in Mubi, 
Nigeria. International Journal of Science and Technology Education Research, 4 (1), 11-17 (2013).

[9] Pant, B.P., and Poudyal, K .N. Evaluation of Global Solar Radiation with single and multiple parameter models in Midwestern region Jumla, Nepal. Research Journal of Physical Sciences, 5(8), 1-6 (2017).

[10] Poudyal, K. N., Bhattrai, B. K., Sapkota, B., and Kjeldstad, B. Estimation of Global Solar Radiation using Sunshine duration in Himalaya region. Journal of the Institute of Engineering, 11(1), 158-164 (2015).

[11] Poudyal, K.N., Bhattrai, B. K., Sapkota, B., Kjeldstad, B. and Daponte, P. Estimation of daily global solar radiation; Nepal experience, Measurement. Measurement, 46 (6), 1807- 1817 (2013).

[12] Muzathik, A. M., Nik, W. S. W., Ibrahim, M. Z., Samo, K., Sopin, K. B., and Alghoul, M. Daily Global Solar Radiation Estimated based on Sunshine hours. International Journal of Mechanical and Materials Engineering, 6(1), 7580 (2011).

[13] Duffie, J. A. and Beckman, W.A. Solar engineering of thermal processes. New York, Wiley, (1991).

[14] Gana, N. N., and Akpootu, D. O. Estimation of Global Solar Radiation using four Sunshine based models in Kebbi, North Western, Nigeria. Advances in Applied Science Research, 4 (5), 409-421 (2013).

[15] Katiyar, A. K. and Pandey, C. K . A Review of Solar Radiation Models-Part I. Journal of Renewable Energy, 2013, 1-11(2013).

[16] Nage, G. D. Estimation of Monthly Average Daily Solar Radiation from Meteorological Parameters: Sunshine Hours and Measured Temperature in Tepi, Ethiopia. International Journal of Energy and Environmental Science, 3 (1), 19-26 (2018).

[17] Newland, F. J. A study of solar radiation models for the coastal region of South China. Solar Energy, 43 (4), 227-235 (1989).
[18] Meenal, R., Boazina, P. G., and Selvakumar, A. I. Temperature based Radiation Models for the Estimation of Global Solar Radiation at Horizontal Surface in India. Indian Journal of Science and Technology, 9(46), 1-6 (2016).

[19] Chen, R., Ersi, K., Yang, J., Lu, S. Z. W. Validation of five global radiation models with measured daily data in China. Energy Conversion and Management, 45, 1759-1769 (2004).

[20] Ituen, E. E., , Esen, N. U. , Nwokolo, S., and Udo, E. G. Prediction of global solar radiation using relative humidity, maximum temperature and sunshine hours in Uyo, in the Niger Delta Region,Nigeria. Advances in Applied Science Research, 3 (4), 1923-1937 (2012).

[21] Adhikari, K. R. Estimation of Global Solar Radiation for the four selected sites in Nepal using sunshine hour, temperature, and relative humidity. Journal of Power and Energy Engineering, 1, 1-9 (2013).

[22] Nwokolo, S. C., and Ogbulezie, J. C. A quantitative review and classification of Empirical models for Predicting Global Solar Radiation in West Africa. Solar Energy, 7 (4), 367-396 (2018).

[23] Chi, V. H. Q., Almorox, J., Ibrakhimov, M., and Saito, L. Empirical models for the estimating daily global solar radiation in Yucatan Peninsula, Mexico. Energy conservation and management, 110, 448-456 (2016).

[24] Ali, B. F., Dehghan, A., and Faghih, A. R. Empirical models for estimating global solar radiation: a review and case study. Renewable and Sustainable Energy Reviews, 21, 798-821 (2013)

[25] Muzathik, A. M., Ibrahim, M. Z., Samo, K. B., and Nik,W. B. W. Estimation of global solar irradiation on horizontal and inclined surfaces based on the horizontal measurements. Energy, 36 (2), 812-818 (2011).

[26] Falayi E., Adepitan, J. O., and Rabiu, A. B. Empirical models for the correlation of global solar radiation with metrological data for Iseyin, Nigeria. International Journal of Physical Sciences, 3 (9), 583-590 (2008). 